\title{
An Exploratory Study of Government Websites Usability in Jordan
}

\author{
Bader Methqal Al Fawwaz, College of Engineering, Design and Physical Sciences, Brunel \\ University, London, UK
}

Vanja Garaj, College of Engineering, Design and Physical Sciences, Brunel University, London, UK

Wamadeva Balachandran, College of Engineering, Design and Physical Sciences, Brunel University, London, UK

\begin{abstract}
The level of usability of the current eGovernment infrastructure in Jordan was investigated by soliciting the views of the management, i.e. the professionals in charge of managing eGovernment projects. The management was addressed in order to gain an understanding of the root causes of the existing usability problems. The study was based on questionnaire which distributed to 37 managers from different institutions providing eGovernment services. The findings show that the main problems undermining the Jordanian eGovernment usability are: 1) the lack of the general usability awareness amongst the management, 2) the lack of clear usability standards and guidelines, 3) the insufficient level of end-user involvement in the process of design and maintenance of eGovernment services, 4) limited budgets and 5) the lack of expert web-designers. Unearthing the views of those in the position to make a change, these findings are useful not only in the context of redefining the strategy for improving eGovernment in Jordan, but also in other developing countries.
\end{abstract}

Keywords: $\quad$ eGovernment, Jordan, Management, Usability, Usability Awareness

\section{INTRODUCTION}

The proliferation of information and communication technology (ICT) over the last two decades has brought about a number of positive changes and delivered significant improvements in the interaction between citizens and their governments.

By way of eGovernment, ICT has greatly enhanced the efficiency and effectiveness of the services that many governments around the world offer to the public - thus supporting economic and social development both locally and globally (Kumar et al, 2007).

The term eGovernment does not have a unique definition. It is often defined as the use of any form of ICT (e.g. the Internet, Wide Area Networks etc.) to support the delivery of government-related information, services and transactions through seamless interactions 
between citizens and all governmental entities (Beynon-Davies, 2007; Fagan, 2006). The United Nations Public Administration Network defines eGovernment as: "utilizing the Internet and the world-wide-web for delivering government information and services to citizen" (UNPAN, 2002, p.1), while the World Bank (2010) defines it as "the use by government agencies of information technologies, such as Wide Area Networks, the Internet, and mobile computing, that have the ability to transform relations with citizens, businesses and other arms of government".

In defining eGovernment, some authors emphasise its business facilitation role. For example, Buckley (2003) defined eGovernment as implementing cost-effective ICT models for all stakeholders (citizens, industry, federal employees) to conduct business transactions online. Poon and Huang (2002) considered eGovernment to be the range of processes implemented by governments to provide the public with e-business solutions (e.g. buying, selling and conducting other types of businessrelated electronic transaction). In this context, eGovernment is seen as part of a wider sphere of so-called eDemocracy (i.e. the electronic communication between government and its users in any shape or form).

The availability of computers and the Internet are not only factors to be considered in any eGovernment form but the gap between the government and citizens' perspectives on eGovernment should be considered. Heeks (2003) and Choudrie et al (2009) mentioned that in the information systems implementation that there is a gap between the reality and design. This is considered one of the main reasons behind eGovernment projects failure in most developing countries.

Despite the proliferation of eGovernment services, governments have faced some challenges in making their websites usable (Soufi and Maguire, 2007). One of these challenges is the lack of understanding eGovernment in government agencies which will affect negatively on usability of websites by ignore users' needs and this will lead to decrease users demand on eGovernment websites.
According to Thomas and Streib (2003) and Kampen et al (2005) that there are some users prefer to obtain informative services instead of integrative services, while, other users are demanding improvement on the existing services instead of launching new online services. These differences make a gap between the supply and demand for eGovernment services. This is due to the low level of standardization for e-services usability from the supply side particularly in the developing countries as most the governments have problems in addressing the citizen's needs to use eGovernment services (Mofleh, 2008).

Casaló et al (2005) stated that failure to achieve acceptable levels of usability for eGovernment services threatens not only the eGovernment initiatives, but also the relationship between the government and citizens in general.

These issues are more significant in developing countries such as Jordan, where the digital divide is wider (Elsheikh et al, 2008), further inhibiting the eGovernment project. Mofleh (2008) and Mohammad (2009) stated that the construction and design of Jordanian eGovernment websites, expectations and needs of end-users have been ignored, and no account given of what Jordanians want from the existing system.

The purpose of this article is to investigate the level of usability of eGovernment from managers' perspective. The study focused on the views of professionals in charge of managing eGovernment projects in Jordan. This study is important as there is a lack of eGovernment usability studies done so far in Jordan.

\section{EGOVERNMENT AND USABILITY}

The term 'usability' refers to the ability to learn, interact with and use a product or service to achieve the purpose it is meant to facilitate. The International Organization for Standardization (ISO) 9241-11 defines usability as "the extent to which a product can be used by specified users to achieve specified goals with effectiveness, efficiency and satisfaction in the specified 
context of use" (Abran et al, 2003, p.326). Nielsen (1993) described usability as a combination of quality components depicting how easy the user interface for a product or service is to operate. These components include learnability, efficiency, memorability, errors and satisfaction.

Some authors define usability as the movement towards making products or services easier to use (George, 1996). While usability is defined in a general context, web usability is more specifically defined as clarity, simplicity, and consistency in the website design in order to allow users to perform their tasks easily (Cappel and Huan, 2007).

Weerakkody and Choudrie (2005) pointed out that website usability needs to be taken seriously in eGovernment projects, especially in the stages of planning, development and implementation. Moreover, Carter and Bélanger (2005) said that users may become frustrated and unlikely to adopt or even use eGovernment services if they encounter problems while using a website.

As eGovernment has become a global fact; Asiimwe and Lim (2010) and Stanziola et al (2006) stated that usability is one of the main problems influencing the adoption and development of eGovernment. Poor usability often prevents eGovernment adoption and development. Furthermore, it affects the success or failure of eGovernment and a low usability index is a major symptom of the failure of an eGovernment project.

Usability plays a key role in ensuring that eGovernment fulfils its aims (Holden et al, 2003). Therefore, eGovernment services must be designed with ease of use being the primary design criterion in order to ensure they are accessible and easily operable by the widest possible pool of users - including people who are disabled (e.g. visual impairment) and those with less than average IT skills (Eynon, 2006; Nielsen, 2000; Shi, 2007).

The usability measures not only how well the website works, but also the degree to which the website meets user needs (Thompson et al, 2003). eGovernment websites have to focus on user satisfaction, control, needs and flexibility.
The failure to achieve the acceptable levels of usability of eGovernment services threatens not only the eGovernment initiatives, but also the relationship between the government and citizens in general (Casaló et al, 2005).

Nielsen (2000) stated that users have very little patience if websites are slow, or difficult to navigate. A well-designed eGovernment website should permit the average user to gain the full understanding of how to operate it after scanning its home page for just a few seconds. Furthermore, the websites should be made operable irrespective of the type of access device used (e.g. mobile phone, classic PC) (Baker, 2009).

eGovernment websites are not always designed with usability in mind. Baker (2009) cited the Council for Excellence in Government and stated that several of non-governmental users do not interact with eGovernment due to difficulty of finding the website information they need. West (2007) made several recommendations that might make eGovernment websites more accessible and usable, including to:

- Standardize templates with consistent navigation; governments need to shift into standardization between all the website agencies. However, to avoid the confusion, it is important to differentiate between different agencies, such as showing the logo of agencies prominently and making significant colour differentials between websites.

- Create accessibility aids to reduce confusion; governments should implement some aids for users, as they sometimes need aids to customize their needs (i.e. change and choose the text size, line spacing, text colour).

- List when pages are updated; government should refer to when pages were last updated.

- Have personalized sections; it is better for a government website to list everything it is able to achieve online in the same place, and also be listed based on groups or categories. 
- Make "Most popular" lists; government website needs to provide boxes with frequently required services to help users utilize the website quickly.

- Make it attractive or interesting; as far as possible without superfluous information and graphics, web pages should be interesting and engaging.

- Fix faulty links; government websites should make sure all its links are not broken, and allow easy clicking and linking to avoid frustration.

- Improve language accessibility; any government website should offer multiple languages to allow any overseas users (i.e. students, tourists) communicating and get their information.

In addition, Nielson (1994) identified a set of usability heuristics for user interface design which are consisting of visibility of system status, match system to the real world, user control and freedom, consistency and standards, error prevention, recognition rather than recall, flexibility and efficiency of use, aesthetic and minimalist design, help users recognize, diagnose and recover from errors, and help and documentation.

\section{1. eGovernment in Jordan}

The Jordanian eGovernment program was launched in 2001. The Program Management Office (PMO) was established by the Ministry of Information and Communications Technology (MoICT) to provide support for the program and manage its functions, which include e-services, shared services, operation management, technology services and change management (Elsheikh et al, 2007).

The eGovernment program in Jordan was initiated as a national program. The idea of the program is to increase the overall quality of the services provided by the Jordanian government - by improving efficiency, accuracy, saving time and costs; and by increasing customer satisfaction, transparency and cross-government integration. These improvements are expected to have a positive effect on government performance and to contribute to the relationships between government, citizens and businesses.

Furthermore, the program is aimed at reducing the complexity for citizens in dealing with government administration, and helping to make the government more transparent, accessible and responsive by providing information and services online (EDS, 2001; MoICT, 2006).

According to Btoush (2009), almost all the websites in Jordan are considered as being at the informative stage, which means they are only providing information about services such as contact numbers, office locations and hours of operation, a general description of the service, and sometimes identifying the processes needed for a particular piece of bureaucracy.

Moreover, around half of the websites can be categorized as being at the interactive stage, which provides communication with the service provider. In this stage, the user is able to communicate with the service provider by downloading basic forms or documents, but they cannot submit the forms online. In addition, although technically queries can be answered via websites, in reality off-line methods (telephone, or more likely, going to an office in person) remain the more reliable ways to obtain information or guidance, such as responding to complaints or suggestions.

The Driver and Vehicle Licensing Department, Borders and Residence Department, Ministry of Education, and Civil Status and Passport Department are the best examples of partial application of the interactive stage.

Some government websites provide complete interaction capabilities. These websites allow users to complete and submit online forms and provide tools for responding to online queries. The Department of Lands and Survey, Greater Amman Municipality, Ministry of Higher Education and Scientific Research, Department of Income and Sales Tax, and Customs Department are the best examples of the fully interactive stage.

The Income and Sales Tax department website is the only one that has reached the intercommunicative stage. In this stage users 
are able to access and complete transactions online. This includes filling forms electronically in order to make payments. Creating and saving their own personalized files or update and modify such files are one of the services offered by Income and Sales Tax department and Greater Amman Municipality to their users. Amman Greater Municipality allows users to give their opinions on some issues, for instance, concerning the best way for solving the heavy traffic problems in the city of Amman.

Based on the five stages model (emerging, enhanced, interactive, transactional and connected), the services offered by the Jordanian government through the websites have so far scored the web measure index of 0.60 (out of 1.00) on the United Nations eGovernment Survey (2008). The same report assessed Jordan's telecommunication infrastructure with an index of 0.17 (out of 1.00) in terms of internet users, PCs, main telephones lines, mobiles and availability of broadband. This measure reflects basic level of the country's e-readiness. (UN Report, 2008).

Mofleh(2008) conducted a website content analysis study in order to measure the usability of eGovernment services websites in Jordan by adopting the same instrument used for conducted the website content analysis studies for the most populated counties in the US by Baker in 2004, and for Trinidad and Tobago ministry websites by Roach in 2007 . The instrument examines six dimensions of government websites of online services. These dimensions included online services, user help provided, ease of navigation, legitimacy, information architecture, and accessibility accommodations.

The reported results have declared a poor usability status of the current websites. The usability of Jordanian websites has averaged $29 \%$. This score is poor compared with the usability average in the study of the most populated counties in the USA, which have an average of $70 \%$ (Baker, 2004), and Trinidad and Tobago ministry websites, which averaged 54\% (Roach, 2007).

Mofleh's websites content analysis of usability revealed that despite the government in
Jordan is providing informative services; however the reality is that the developed websites ignored in a way the needs of the users and not meet their expectations. Accordingly, this ignorance built gap between the government and users perspectives about eGovernment.

This result shows that Jordanian government websites are in the informative stage, and have a very poor design (hard to navigate, not user friendly) and do not meet citizens' needs. Moreover, there are problems with the construction of the Jordan government websites, indicating a lack of understanding of basic standards to deliver well-constructed eGovernment services.

\section{METHODOLOGY}

\subsection{The Study}

An exploratory study was conducted to investigate the level of usability of the current eGovernment in Jordan from the management perspective. The study focused on the views of professionals in charge of managing and maintaining eGovernment projects in Jordan. The management was addressed in order to gain an understanding of the root causes of the existing usability problems. According to Wang and Huang (2009), professionals can carry out structured assessment and answer questions quickly and directly.

\subsection{Sample}

The study involved a sample of 37 managers, in various capacities, and all were responsible for the uptake of eGovernment in Jordan. This number has been as sufficient to provide reliable data. Obtaining this number of sample was based on the ability to access into the officials' managers and time availability. The websites for this study involved typical types of public services in Jordan. The sample was represented the following governmental institutions (Table 1):

The study participants were aged between 22 to 65 years, with the majority (over 60\%) being between 22 to 40 years. $76 \%$ of the 
Table 1. The study sample

\begin{tabular}{|l|}
\hline \multicolumn{1}{|c|}{ Government Institutions } \\
\hline Civil Status and Passport Department \\
\hline Driver and Vehicle License Department \\
\hline Education Ministry \\
\hline Income and Sales Tax Department \\
\hline Interior Ministry \\
\hline Jordan Customs Department \\
\hline Lands and Surveys Departments \\
\hline Social Security Corporation \\
\hline
\end{tabular}

participants were male and $24 \%$ were female. The majority of the participants hold bachelor degrees (54\%) in disciplines such as computer science, computer information systems, computer engineering, and management information systems; around $32 \%$ had postgraduate degrees.

$24 \%$ of the participants have worked with the eGovernment project for more than 4 years, $41 \%$ for between 2 and 4 years, $22 \%$ for 1 to 2 years and $13 \%$ for less than 1 year. Roles of the participants varied from one institution to another, their positions were varied from manager of information technology, manager of eGovernment project, manager of administrative development and training to computer engineer and programmer.

\subsection{Procedure}

This study applied the questionnaire technique. According to Hsieh and Huang (2008) questionnaire is an easy, inexpensive, effective, and efficient ways to investigate the usability problems. A structured questionnaire has been employed; the answer sheet was requiring participant to choose one of the alternatives offered for each question. The questionnaire items have been measured using a standard five point likert scale.

The questionnaire was organised into sections; the introduction section (5 questions) covered the demographics and professional status of the participants and the level of their engagement and experience with the eGovernment in Jordan. The second section (4 questions) addressed the understanding of the eGovernment and usability issues while the last section (9 questions) covered the factors affecting the usability of eGovernment in Jordan.

The questionnaire was originally designed in English and it was then translated into Arabic, the mother tongue of the participants in order to achieve the full understanding of the questions. All the participants were visited personally by the lead author of this paper. The questionnaire took on average 20 minutes to complete. On completion of all the participants, the questions and their responses have been coded to be analysed using SPSS software.

\subsection{Reliability}

To ensure high data reliability, a pilot study was run and several changes to the draft questionnaires were made based on the feedback. In addition, Cronbach alpha test was used to assess the reliability of the obtained data. Cronbach alpha was found to be above 0.70 (varied between 0.87-0.94). Such values are considered acceptable according to Hair et al (2006).

\section{OUTCOMES}

It was clear that nearly $67 \%$ of respondents think that usability is an important element of success or failure of eGovernment projects, while $8 \%$ of respondents thought the opposite, and $25 \%$ of respondents did not know much about usability. 
The usability of eGovernment in Jordan was also addressed in terms of the issue of user interfacing. $59 \%$ of the participants have experienced average and below average satisfaction with the interfaces of eGovernment websites, while just $35 \%$ thought the interfacing was very good and good, and $6 \%$ poor.

The user's experience was measured from the feedback and complaints sent to the service providers. Accordingly, the most common problems were mentioned by the users of eGovernment website (user's perspective) were also investigated.

It was found that $27 \%$ of the system users believed that the current website is a bit confusing to follow, and difficult to navigate. Additionally, $25 \%$ of the feedbacks which obtained from the users were not happy about the appearance of the website while $22 \%$ considered lack of customization as a major problem. Moreover, $19 \%$ of the system user's believed that the website does not have an efficient search to facilitate information acquirement.

Furthermore, as shown in (Table 2), the results showed that around $59 \%$ of respondents did not pay attention to the end-user requirements before establishing the eGovernment websites, while $35 \%$ did. Moreover, after launching the eGovernment system, only $45 \%$ of respondents investigated the requirements of the end-users for further developments.

Moreover, it is observed that $57 \%$ of respondents believe that a mechanism such as email and FAQs is sufficient to address the problems encountered by the users, while $43 \%$ of respondents had the opposite views. As for the incentives, the majority of the respondents (78\%) stated that the government in Jordan does not offer any incentives to encourage the usage of its eGovernment websites.

After asking the managers about their views on the biggest challenges of making a website usable to the end-users (Table 3), 73\% thought that lack of awareness of usability amongst the management is the first challenge, followed by lack of involvement of the end-users in the state of design (62\%). In addition, $54 \%$ focused on lack of budget as the main challenge, followed by $48 \%$ for lack of feedback from end-users. Finally, the lack of expert website designers and management problems were taken $48 \%$ and $29 \%$ respectively as the major challenges.

When the respondents were asked what resources they thought would be most helpful to enhance and increase usability of existing eGovernment websites (Table 4), 78\% indicated for clear guidelines and standards, followed by $67 \%$ for involving end-users, then $66 \%$ increased budget, and finally $64 \%$ for more well-trained staff would have the biggest impact.

Additionally, as staff training is considered important factor of any project successful, therefore this was investigated with a focus on the usability aspects. As shown in (Table 5), it was noticed that $62 \%$ of the respondents (this includes all staff who are in charge of running eGovernment services) did not attend any training on the usability of eGovernment websites before or after the project was established, while only $35 \%$ mentioned that they did some training sessions.

Table 2. Paying attention to end-users

\begin{tabular}{|l|l|l|l|l|l|}
\hline & $\begin{array}{c}\text { Yes, } \\
\text { Possibly } \\
\text { Yes }\end{array}$ & Not Sure & $\begin{array}{c}\text { No, } \\
\text { Possibly } \\
\text { No }\end{array}$ & Mean & $\begin{array}{c}\text { Std. } \\
\text { Deviation }\end{array}$ \\
\hline $\begin{array}{l}\text { Paid attention to the end user requirements } \\
\text { before establishing the eGovernment } \\
\text { website }\end{array}$ & $35 \%$ & $6 \%$ & $59 \%$ & 2.51 & 1.909 \\
\hline $\begin{array}{l}\text { Surveyed the requirements of end user after } \\
\text { launching eGovernment system for further } \\
\text { improvement }\end{array}$ & $45 \%$ & $4 \%$ & $51 \%$ & 2.78 & 1.902 \\
\hline
\end{tabular}


Table 3. Biggest challenges of making a website usable for end-users

\begin{tabular}{|l|l|l|l|l|l|}
\hline & $\begin{array}{c}\text { Strongly } \\
\text { Agree, } \\
\text { Agree }\end{array}$ & Not Sure & $\begin{array}{c}\text { Strongly } \\
\text { Disagree, } \\
\text { Disagree }\end{array}$ & Mean & $\begin{array}{c}\text { Std. } \\
\text { Deviation }\end{array}$ \\
\hline Lack of awareness of usability & $73 \%$ & $8 \%$ & $19 \%$ & 4.72 & 0.450 \\
\hline Not involving end-user in the stage of design. & $62 \%$ & $11 \%$ & $27 \%$ & 3.56 & 1.385 \\
\hline Lack of budget & $54 \%$ & $16 \%$ & $30 \%$ & 3.45 & 1.282 \\
\hline Lack of feedback from end-users & $48 \%$ & $23 \%$ & $29 \%$ & 3.40 & 1.517 \\
\hline Lack of expert website designers & $47 \%$ & $26 \%$ & $27 \%$ & 3.08 & 1.299 \\
\hline Management problems & $30 \%$ & $14 \%$ & $56 \%$ & 2.62 & 1.497 \\
\hline
\end{tabular}

Table 4. Improving and increasing usability

\begin{tabular}{|l|l|l|l|l|l|}
\hline & $\begin{array}{c}\text { Strongly } \\
\text { Agree, } \\
\text { Agree }\end{array}$ & \multicolumn{1}{|c|}{ Not Sure } & $\begin{array}{c}\text { Strongly } \\
\text { Disagree, } \\
\text { Disagree }\end{array}$ & Mean & $\begin{array}{c}\text { Std. } \\
\text { Deviation }\end{array}$ \\
\hline Clear guidelines and standards & $78 \%$ & $12 \%$ & $10 \%$ & 3.97 & 1.166 \\
\hline Involving end-users & $67 \%$ & $19 \%$ & $14 \%$ & 3.83 & 1.236 \\
\hline More budget & $66 \%$ & $13 \%$ & $21 \%$ & 3.75 & 1.320 \\
\hline Trained staff & $64 \%$ & $14 \%$ & $22 \%$ & 3.64 & 1.274 \\
\hline
\end{tabular}

Table 5. Attending training

\begin{tabular}{|l|l|l|l|l|l|}
\hline & $\begin{array}{c}\text { Yes, } \\
\text { Possibly } \\
\text { Yes }\end{array}$ & Not Sure & $\begin{array}{c}\text { No, } \\
\text { Possibly } \\
\text { No }\end{array}$ & Mean & $\begin{array}{c}\text { Std. } \\
\text { Deviation }\end{array}$ \\
\hline $\begin{array}{l}\text { Attending training on usability ofeGovernment } \\
\text { websites before or after the project }\end{array}$ & $35 \%$ & $3 \%$ & $62 \%$ & 2.56 & 1.818 \\
\hline
\end{tabular}

\section{DISCUSSION}

The conducted study has revealed that eGovernment systems in Jordan did not pay significant attention to the end users' requirements before establishing the websites or after launching them for further developments. This is in agreement with Mofleh (2008) and Mohammad (2009), who pointed out that during the construction and design of Jordanian eGovernment websites, the expectations and needs of end-users have been ignored, and no account taken of what they want from the existing system.
Implementing imported systems from developed countries has been perceived by the Jordanian government as an appropriate form of action to adopt such new services. However, this is considered as a clear indication that the requirements for the real users as well as other factors such as knowledge, culture and the different needs have been ignored. Mofleh (2008) mentioned that Jordanian government is importing methods applied in advanced countries with the belief they are adding value to citizens.

On the other hand, there is a lack of trust between the users and eGovernment project. This sometimes considered as an encouraging 
reason for the users to be uncooperative in participation. Users believe that government will not consider their views seriously and will apply its proposal at the end. According to Szeremeta and Kerby (2005) users will not answer questionnaire or even not participate in eGovernment if there is no trust to deal with their views seriously by the government.

The responsible staff in eGovernment project in Jordan should consider involving end-users and consider their feedback in the initial stage of websites design seriously in order to achieve satisfied level of usability. Stanziola et al (2006) mentioned that the participation of users during the design process increases their feeling of not being ignored, and encourages the adoption of any new system.

Furthermore, although around two third of the respondents believed that the usability is important factor for eGovernment project to become either successful or failure; however, lack of usability awareness remains one of the biggest challenging factors for making websites usable for the Jordanian end-users. This strongly suggests a very limited understanding of usability and its importance for the success of the websites.

This is not surprising as eGovernment project in Jordan has been facing problems with the majority of staff not attending any training on the usability of eGovernment before or even after the establishment of the project to understand the system within a limited budget. Therefore, eGovernment project in Jordan should direct its effort towards obtaining qualified staff, providing training schemes and other necessary skills as well as providing higher budgets in order to ensure a successful project implementation.

The conducted study also tried to know the respondents views about the websites interfaces of their institutions. Accordingly, it concluded that over half of respondents experienced average and below average satisfaction of the interfaces of the current eGovernment websites in Jordan. It seems that the lack of applying the website usability standards affected the quality of the interfaces of the Jordanian governmental websites.
This is not surprising as Mofleh (2008) stated that eGovernment websites in Jordan were developed by the IT government departments' teams, and the rest were developed by different certified IT companies in Jordan, and each one has a different layout and architecture. This need to be changed and Jordanian government websites should follow the usability standards in order to make its websites usable and consistent.

Finally, the Jordanian government has invested in eGovernment, however; it seems that the investment has not been accompanied with frameworks or guidelines on eGovernment usability to ensure the success of this project and to encourage both citizens and government to fully utilise them. The eGovernment in Jordan should adapt to users' needs and expectations, and this will not be achieved unless they prioritise the usability dimension.

\section{CONCLUSION}

Despite several studies having been done about eGovernment in Jordan, there is still a lack of research to tackle usability issues. Therefore, this exploratory study is trying to fill this gap by focusing on the views of professionals in charge of managing eGovernment project in Jordan from the perspective of eGovernment usability.

The outcome has revealed that there are still no clear guidelines with regards to websites usability that the websites managements should follow, particularly lack of usability awareness amongst the management and citizen participation at the website design phase. These are considered as challenges facing usability of Government websites in Jordan.

Although all the investment by the Jordanian government into the eGovernment project, the absence of clear guidelines to govern eGovernment project initiation and operation might inhibit many difficulties to take off.

In addition to the fact that Jordanian governmental websites have not accommodated usability standards, there is no awareness of users' needs and expectations. The limited 
budget of Jordanian eGovernment project and lack of expert web-designers are also considered as significant problems encountering the improvement of the usability of eGovernment websites in Jordan.

It is important at this stage that the Jordanian eGovernment should address the current problems to ensure the provision of usable eGovernment websites in Jordan.

The study adds to the existing body of knowledge and it is useful not only from the perspective of improving Jordanian eGovernment services but also to those of other developing countries. At the methodological level the study offers an upgrade to the existing methods used.

The study was only focused on highlighting reasons behind the lack of usability from managers' perspective and it did not include the end-users. The next phase of the research work will be focused on the end-users.

\section{REFERENCES}

Abran, A., Khelifi, A., Suryn, W., \& Seffah, A. (2003). Usability Meanings and Interpretations in ISO Standards. Software Quality Journal, 1(4), 325-338. doi:10.1023/A:1025869312943

Asiimwe, E., \& Lim, N. (2010). Usability of Government Websites in Uganda. Electronic. Journal of E-Government, 8(1), 1-12.

Baker, D. (2004). E-government: website usability of the most populous counties. PhD Thesis, Arizona, State University, USA.

Baker, D. (2009). Advancing E-Government performance in the United States through enhanced usability benchmarks. Government Information Quarterly, 26(1), 82-88. doi:10.1016/j.giq.2008.01.004

Beynon-Davies, P. (2007). Models for e-government. Transforming Government: People. Process and Policy (1), 7-28.

Btoush, M. (2009). Evaluation of e-government services in Jordan: providers \& users' perceptions. $\mathrm{PhD}$ thesis, Sheffield Hallam University, UK.

Buckley, J. (2003). E-service quality and the public sector. Managing Service Quality, 13(6), 453-462. doi:10.1108/09604520310506513
Cappel, J., \& Huang, Z. (2007). A usability analysis of company websites. Journal of Computer Information Systems, 48(1), 117-123.

Carter, L., \& Bélanger, F. (2005). The utilization of e-government services: Citizen trust, innovation and acceptance factors. Information Systems Journal, 15(1), 5-25. doi:10.1111/j.1365-2575.2005.00183.x

Casaló, L., Flavián, C., \& Guinaliú, M. (2005). The role of accessibility and commitment in the development of an e-government strategy. eGovernment Workshop '05 (eGOV05). September 13, 2005. West London, UK: Brunel University.

Choudrie. J, Wisal. J and, Ghinea. G (2009), "Evaluating the usability of developing countries' e-government sites: a user perspective", Electronic Government, an International Journal - Vol. 6, No.3 pp. $265-281$.

Electronic Data Systems Corporation's (EDS). (2001). E-Government Blueprint and Roadmap" final report, September.

Elsheikh, Y., Cullen, A., \& Hobbs, D. (2007). Towards e-government in the Middle East: A Jordanian Study. IADIS International Conference, ISBN: 978972-8924-44-7.

Elsheikh, Y., Cullen, A., \& Hobbs, D. (2008). “eGovernment in Jordan: challenges and opportunities", Transforming Government: People. Process and Policy, 2(2), 83-103.

Eynon, R. (2006). Breaking Barriers to eGovernment, overcoming obstacles to improving European public services. Oxford Internet Institute, University of Oxford.

Fagan, M. (2006). Exploring city, county and state e-government initiatives: An East Texas perspective. Business Process Management Journal, 12(1), 101-112. doi:10.1108/14637150610643797

George, H. (1996). The good usability handbook. London: McGraw-Hill.

Hair, J., Anderson, R., Tatham, R., \& Black, W. (2006). Multivariate Data Analysis (6th ed.). Upper Saddle River: Prentice-Hall.

Heeks, R. (2003), "Most eGovernment- for-Development Projects Fail: How Can Risks be Reduced?" Government Working Paper Series, IDPM, University of Manchester, UK. 
Holden, S. H., Norris, D. F., \& Fletcher, P. D. (2003). Electronic government at the local level: Progress to date and future issues. Public Performance \& Management Review, 26(4), 325-344. doi:10.1177/1530957603026004002

Hsieh, S., \& Huang, S. (2008), "Usability Evaluation: ACase Study", APIEMS 2008 Proceedings of the 9th Asia Pacific Industrial Engineering \& Management Systems Conference.

Kampen, J., Snijkers, K., \& Bouckaert, G. (2005). Public priorities concerning the development of e-Government in Flanders. Social Science Computer Review, 23(1), 136-139. doi:10.1177/0894439304271557

Kumar, V., Mukerji, B., Butt, I., \& Persaud,A. (2007). Factors for Successful e-Government Adoption: A Conceptual Framework. The Electronic. Journal of E-Government, 5(1), 63-76.

Mofleh, S. (2008). Managing e-government projects: the gap between supply and demand. $\mathrm{PhD}$ thesis, Bristol University, UK.

Mohammad, H., Almarabeh, T., \& Abu Ali, A. (2009). E-government in Jordan. European Journal of Scientific Research, 35(2), 188-197.

MoICT. (2006). Jordan e-Government Program. Ministry of Information and Communications Technology. eGovernment Strategy.

Nielsen, J. (1993). Usability Engineering. Academic Press.

Nielsen, J. (1994). Heuristic evaluation. In J. Nielsen \& R. L. Mack (Eds.), Usability Inspection Methods. New York, NY: John Wiley \& Sons.

Nielsen, J. (2000). Designing Web Usability. The Practice of Simplicity. New Riders Publishing.

Poon, S., \& Huang, X. (2002). Success at EGoverning. A Case Study of ESD Life in Hong Kong. Electronic Markets, 12(4), 270-280. doi:10.1080/101967802762553530

Roach, C. (2007). E-government: Usability of Trinidad and Tobago Ministry Websites. PhD Thesis, Arizona State University, USA.

Shi, Y. (2007). The accessibility of Chinese local government web sites: An exploratory study. Government Information Quarterly, 24(2), 377-403. doi:10.1016/j.giq.2006.05.004
Soufi, B., \& Maguire, M. (2007). Achieving Usability Within E-Government Web Sites Illustrated by a Case Study Evaluation. Human Interface and the Management of Information. Interacting in Information Environments, Springer, 777-784.

Stanziola, E., Minuto Espil, M., Landoni, L., \& Montoya, S. (2006). Hidden Negative Social Effects of Poor eGovernment Services Design. (Eds.): EGOV 2006, LNCS 4084, Springer-Verlag Berlin Heidelberg, 150-161.

Szeremeta, J., \& Kerby, R. (2005) "E-GOVERNMENT: PROVIDING VALUE TO CITIZENS", 6th Global Forum on Reinventing Government Towards Participatory and Transparent Governance, May 2005, Seoul, Republic of Korea.

Thomas, J. C., \& Streib, G. (2003). The new face of government: Citizen-initiated contacts in the era of e-Government. Journal of Public Administration: Research and Theory, 13(1), 83-102. doi:10.1093/ jpart/mug010

Thompson, K. M., McClure, C. R., \& Jaeger, P. T. (2003). Evaluating federal websites: Improving eGovernment for the people. In J. F. George (Ed.), Computers in society: Privacy, ethics, and the Internet (pp.400-412). Upper Saddle River, NJ: Prentice Hall.

UN. United Nations eGovernment Survey. (2008). From e-Government to Connected Governance. United Nations.

UNPAN, United Nations Public Administration Network. (2002). Benchmarking E-government: A Global Perspective. Assessing the Progress of the UN Member States, The United Nations.

Wang, X., \& Huang, W. (2009). Lund University Website Evaluation: Focus on homepage and English research pages. Master Thesis, Lund University, Sweden.

Weerakkody, V., \& Choudrie, J. (2005). Exploring E-Government in the UK: Challenges, Issues and Complexities. Journal of Information Science and Technology, 2(2), 26-44.

West, D. M. (2007). Global E-Government, 2007. Providence: Centre for Public Policy, Brown University.

World Bank. (2010). The official website of The World Bank. Retrieved May 25, 2010, from http:// go.worldbank.org/M1JHE0Z280 
Bader Methqal AlFawwaz obtained a PhD from the School of Engineering and Design, Brunel University, UK in 2012. His research interests span different areas of information science, with a particular focus on e-government services.

Vanja Garaj holds a BSc in Product Design from the University of Zagreb, Croatia and a PhD in Systems Design from Brunel University, UK. He currently works as a Senior Lecturer in Digital Design at the College of Engineering, Design and Physical Sciences, Brunel University. His research focuses on human factors within the contexts of product, service and environmental design - with a particular interest in digital media.

Wamadeva Balachandran received the BSc degree from the University of Colombo, Sri Lanka in 1970 and the MSc and PhD degrees from the University of Bradford, UK in 1975 and 1979, respectively. He is a Professor of Electronics Systems and Director of the Centre for Electronic Systems Research at Brunel University, UK. He is a Visiting Professor at University of Mansoura, Egypt and University of Donguan in China. He was a Visiting Scholar in the School of Engineering and Applied Science, University of California, Los Angeles, in 2004 - sponsored by the Royal Academy of Engineering, UK. He is actively pursuing research on electrohydrodynamics, charge particle dynamics, electroaerosols, GPS navigation systems, m-health, biometrics and lab-on-a-chip technology. He has published over 275 journal and conference papers, and filed twelve patent applications in these fields. He was the recipient of IEEE John Melcher Best Paper Award in 2000. Professor Balachandran is a Member of the Electrostatic Processes Committee of the IEEE Industry Applications Society. He is a Fellow of the Institute of Engineering and Technology (UK), Institute of Physics (UK), Institute of Measurement and Control (UK) and Royal Society of Arts (UK). 